\title{
CES
}

COOPERATIVISMO E ECONOMÍA SOCIAL

Núm. 41 (2018-2019), páxs. 25-44

ISSN: $1130-2682$

\section{COOPERATIVES AND PROFESSIONAL FOOTBALL: \\ CAN A COOPERATIVE BE AN ADEQUATE \\ LEGAL STRUCTURE FOR A CLUB? \\ AN ANALYSIS UNDER THE PECOL PRINCIPLES}

COOPERATIVAS E FUTEBOL PROFISSIONAL:

UMA COOPERATIVA PODE SER UMA ESTRUTURA

JURÍDICA ADEQUADA PARA UM CLUBE?

UMA ANÁLISE SOB OS PRINCÍPIOS DA PECOL

MARIA DE FÁtima RibeIRO*

Recepción: 19/7/2019 - Aceptación: 4/11/2019

* Professora da Faculdade de Direito da Universidade Católica Portuguesa. R. de Diogo Botelho 1327, 4169-005 Porto. Endereço de correio electrónico: mribeiro@ porto.ucp.pt. 


\begin{abstract}
Football clubs are traditionally organised under an associative legal form. Their objective is therefore not to obtain profit, but to pursue an activity that provides general benefits to the community (both to members and non-members of the association). However, severe financial and management issues have recently come to light in the professional football industry. Good governance is required in order to surpass those problems. The choice of legal form is a main driver of good governance, and that is the reason why under current Portuguese law only companies are allowed to enrol in professional football competitions. But this legislative option has not proven to be the best solution. In this paper, we assess the adequacy of the cooperative form as an organisational option, focusing on the substantial rules of PECOL (Principles of European Cooperative Law), which lays out the "ideal" legal identity of cooperatives, as well as on examples from specific jurisdictions.
\end{abstract}

KEYWORDS: Cooperative football clubs. Professional football industry. 
CONTENTS: 1. THE PROBLEMS THAT LED TO THE RISE OF PROFIT-MAKING COMPANIES AS THE PREFERRED LEGAL STRUCTURE IN PROFESSIONAL FOOTBALL. 2. THE REMAINING ISSUES. 3. DEFINITION AND OBJECTIVES OF COOPERATIVES AND PROFESSIONAL FOOTBALL. 4. MEMBERSHIP IN COOPERATIVES AND PROFESSIONAL FOOTBALL. 5. GOVERNANCE IN COOPERATIVES AND PROFESSIONAL FOOTBALL. 6. FINANCIAL STRUCTURE OF COOPERATIVES AND PROFESSIONAL FOOTBALL. 7. COOPERATIVES' FINANCIAL AND MANAGEMENT AUDIT AND PROFESSIONAL FOOTBALL. 8. THE POSSIBLE ADVANTAGES OF COOPERATIVES AS THE LEGAL STRUCTURE OF CLUBS IN PROFESSIONAL AND AMATEUR FOOTBALL.

\section{THE PROBLEMS THAT LED TO THE RISE OF PROFIT-MAKING COMPANIES AS THE PREFERRED LEGAL STRUCTURE IN PROFESSIONAL FOOTBALL}

$\mathrm{G}$ ood governance is essential to the professional football industry. To support effective club management and to navigate an often challenging economic context, an adequate choice of legal form is required. Good governance is essential to the professional football industry. To support effective club management and to navigate an often challenging economic context, an adequate choice of legal form is required. Under current Portuguese law, only companies are allowed to enrol in professional football competitions. This legislative option is essentially justified by the same aforementioned reasons. This legislative option is essentially justified by the same aforementioned reasons ${ }^{1}$.

A sports company can be founded with or by a club - but it can also be established without a club's participation. In addition, a club can be transformed into a sports company - in which case it would no longer be a club. Finally, a sports company can be the result of an operation by which a club incorporates part or parts of its business. By spinning off the assets required to perform the economic activities related to the participation in competitions in a particular or a series of sports areas ${ }^{2}$, the club remains a separate legal entity. The club will therefore necessarily be one of the shareholders of the newly established sports company (or even its only shareholder, holding $100 \%$ of capital shares) ${ }^{3}$. Until recently, the latest means of establishing a sports company has been undertaken by most

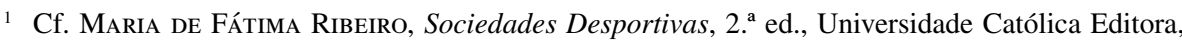
Porto, 2017, pp. 14 ff.

2 Cf. Maria de Fátima Ribeiro, "A responsabilidade da SAD pelas dívidas do clube: o artigo 22. , n. ${ }^{\circ}$ 4, da LSD", in Revista de Direito do Desporto, n. ${ }^{\circ}$ 2, 2019, 7-18, pp. $7 \mathrm{ff}$.

3 Cf. Maria de Fátima Ribeiro, Sociedades Desportivas, cit., pp. 66 ff.
} 
Portuguese clubs which wanted to do so (or were forced to, as a pre-condition to take part in professional competitions).

A club is usually organised under an associative legal form. Its goal is therefore not to obtain profit, but to pursue an activity that provides general benefits to the community (that is, to members and non-members of the association). Clubs are expected to contribute to general welfare, along with the State, by facilitating access to the practice of physical activity and promoting a healthy life style. In contrast, sports companies must (under Portuguese law) have the main goal of obtaining and maximising profits, in order to distribute them to their shareholders ${ }^{4}$.

Another key aspect to consider are governance rules. Typically, legal biases are far less strict for non-profit associations than for private companies ${ }^{5}$. In order to ensure good governance requirements are adhered to by club management, in some countries (as is the case with Portugal) only sports companies are allowed to participate in professional competitions. In countries where this is not mandatory, the less strict legislative requirements are regarded as the true reason for clubs to remain non-profitable 6 . Yet, evidently, good governance (effective management, accountability and transparency) is essential to attract significant external investment.

These opposed goals raise important questions when trying to determine the true role of these entities.

On the one hand, if the company has to pursue maximum profit and needs to attract investors, it will not free willingly contribute to social welfare. In fact, any activity serving this purpose would only be admitted if practiced as an instrumental way to serve the maximum profit (v.g., as a marketing tool). Otherwise, the specific uninterested acts could be void, leading to directors' liability; and, of course, it would deter all purely financial investment.

On the other hand, however, the success of this economic activity depends almost entirely on the true participation of the fans. Besides, positioning professional football as a merely economic activity would, without any doubt, lead to the end of an attractive business. Furthermore, the positive social impact created by the club, as described above, would be lost.

\footnotetext{
${ }^{4}$ Cf. Maria de Fátima Ribeiro, Sociedades Desportivas, cit., p. 162.

5 Cf. the legislative evolution in France, described by Benoît Senaux, "The regulated commercialisation of french football", in The Organisation and Governance of Top Football Across Europe. An Institutional Perspective (Hallgeir Gammelsæter/Benoît Senaux), Routledge, New York/London, 2011, 123-137, pp. $129 \mathrm{ff}$.

6 Cf. Anne-Line Balduck/StefFie Lucidarme, "Belgian football. A uniting force in a two-track policy?", in The Organisation and Governance of Top Football Across Europe. An Institutional Perspective (Hallgeir Gammelsæter/Benoît Senaux), Routledge, New York/London, 2011, 107-122, pp. $115 \mathrm{ff}$.
} 
It would therefore be relevant to ensure that the mandatory establishment of sports companies does not, in any way, lead to the extinction of non-profit forms of club organisation. To address that need, a sports company can be complemented with a non-profit entity, dedicated to the development of non-profit activities ${ }^{7}$. Generally, a club is a non-profit association, but this paper explores the possibility and adequacy of a cooperative organisation. It will also analyse the cooperative form as an alternative to the sports company itself; seeking to determine whether it can support effective management and the overcoming of the financial issues that surround professional football.

The issues relating to club governance are generally identical to those that affect family enterprises: the control by a single shareholder (or a small group of shareholders), the appointment of directors on the basis of confidence (rather than professional skills and ethical behaviour), the lack of information disclosure ${ }^{8}$, and poorly effective control by the supervisory board. The mandatory constitution of a sports company was expected to avoid the perpetuation of these problems. The issue is that it actually does not seem to have had that effect ${ }^{9}$.

\section{THE REMAINING ISSUES}

When the club is the main shareholder of the company, it is widely accepted that the president of the association is also the president of the company's board

\footnotetext{
7 Cf. the analysis of Armin Wiedenegger/Alexander Kern/Maria Rupprechter, "The Choice of Legal Form and its Effects on Good Governance: A Case Study of an Austrian Professional Soccer Club", in Ekonomika a Management, Issue 3, 2012, 23-43, pp. 27 ff. In Switzerland, although some clubs choose to become a limited company, the League encourages clubs to retain an associative structure within the club - the association will run the amateur section and, at the same time, be useful in protecting the club's assets, especially the intangible ones, such as their name (should the company go bankrupt). Cf. Olivier Mutter/Nicolas Huber, "Swiss football. Finding alternatives to TV right revenues", in The Organisation and Governance of Top Football Across Europe. An Institutional Perspective (Hallgeir Gammelsæter/Benoît Senaux), Routledge, New York/London, 2011, 93-106, p. 101.

8 The lack of information disclosure leads to less external investment $-v . g$., if the club does not disclose information to shareholders, it will necessarily be difficult to attract new ones, or to make the existing shareholders believe they shoud invest more. Relevant information is, for instance, the information on the ownership of the club, its constitution and on the running of the club (including the information on the board of directors, financial performance, assets, liabilities and strategy). Cf. Jonathan Michie/Christine Oughton, "The Corporate Governance of Professional Football Clubs in England", cit., pp. 519 ff. But good corporate governance requires the sports company to also disclose information and efficiently communicate with other stakeholders, including supporters (for the analysis of the special characteristics of football supporters as costumers, Cf. JoNATHAN MichiE/ Christine Oughton, "The Corporate Governance of Professional Football Clubs in England", cit., pp. 522 ff.).

9 Cf. Maria de Fátima Ribeiro, “A insolvência do clube e a sociedade desportiva”, in Revista de Direito Comercial, https://www.revistadedireitocomercial.com/, 2019, 229-266, passim.
} 
of directors. As a result, the basic rules of governance are compromised - both in terms of decision-making autonomy and the professionalism of management ${ }^{10}$. Furthermore, external investors will not be attracted to a company presenting such an opaque organisation. The financial problems persist, as they are usually the result of poor governance and lack of investment ${ }^{11}$.

And in cases where the club is not the main shareholder (or not even a shareholder at all) the sports company risks losing its own identity, therefore reducing its market value. This set-up is often the result of contractual rules established by the investor to control business risks, by which the the role of the club is minimised in an attempt to maximise revenue. Further negative consequences might arise, such as the emergence of serious legal conflicts between clubs and the sports companies they created.

So, ideally, both the club and the company should partake in the sportive project. But specific regulation is required to prevent unnecessary dispute ${ }^{12}$, promote investment and ultimately support the development of sports entities. This specific regulation has to take into account three important aspects: investors (whether supporters or purely financial investors) will only seek limited liability structures; supporters should be encouraged to acquire financial ownership rights, thereby also acquiring some influence over structure related decisions (the alignment of supporters is crucial for the success of any sports business); the prevalence of key

\footnotetext{
${ }^{10}$ Analysing English and Scottish experience on professional clubs frequently structured as limited liability companies, STEPHEN Morrow, "History, longevity, and change. Football in England and Scotland", in The Organisation and Governance of Top Football across Europe. An Institutional Perspective (Hallgeir Gammelsæter/Benoît Senaux), Routledge, New York/London, 2011, 46-61, p. 50 , claims that " $[\mathrm{w}]$ hile the structure normally results in a separation between ownership and control, in football the two often continue to overlap".

${ }^{11}$ As has been written by Christos Anagnostopoulos, "The Battlefield of Greek Football. Organising Top-Tier Football in Greece", in The Organisation and Governance of Top Football across Europe. An Institutional Perspective (Hallgeir Gammelsæter/Benoît Senaux), Routledge, New York/London, 2011, 209-223, p. 217, referring to the Greek situation, but illustrating the reality in most countries: "[t]hat said, all football companies in Greece are owned by family groups (in some cases through a family's holding company), or individuals who are perceived supporters of the club and whose priority has always been sporting success rather than financial performance. As a general rule, Greek clubs share a long tradition of receiving paternalistic support from wealthy business people. Because of the extremely low possibility of making a return on their investments club owners seem to spend their personal funds in an endeavour to acquire social status and possibly political influence in order to facilitate other types of businesses they are involved in".

${ }^{12}$ And even to prevent the loss of identity of the sports company's project. As can be seen in Germany, football clubs were allowed to create joint stock companies since 1998, but the German FA demands that the association retains 50 percent plus one voting rights (with the exception of clubs that were already closely linked to a company at the time, and of the legal form of the sports company as a $\mathrm{GmbH} \& \mathrm{Co}$. KGaA, in which the autonomy of the club is preserved by law): the $50+1$ rule.
} 
governance rules should be ensured, such as rules on information disclosure and management control ${ }^{13}$.

Once the value of the existence of the club has been demonstrated, despite the creation of a sports company, we should now consider the adequacy of the cooperative form as an organisational option ${ }^{14}$. The choice of legal form is a main driver of good governance ${ }^{15}$; so, in order to answer our question, we shall briefly consider a cooperative's main goals and governance rules. For that purpose, we will focus on the substantial rules of PECOL (Principles of European Cooperative Law), which lays out the "ideal" legal identity of cooperatives ${ }^{16}$, and point out examples of specific jurisdictions and the regulation of the societas cooperativa europaea.

\section{DEFINITION AND OBJECTIVES OF COOPERATIVES AND PROFESSIONAL FOOTBALL}

A cooperative is a legal person (having autonomous legal subjectivity and, generally, patrimonial autonomy ${ }^{17}$ - therefore justifying limited liability of the members, who are not liable for the cooperative's debts ${ }^{18}$ ) - that carries on any

${ }^{13}$ Cf. Stephen Morrow, "History, longevity, and change. Football in England and Scotland", cit., pp. $51 \mathrm{ff}$.

${ }^{14}$ As is considered in a document released by The Football Association Limited (UK, 2015), entitled Club Structures. A Guide to Club Structures for National League System and other Football Clubs, 1-46, pp. 6 ff., specifically pp. 13 ff. (about "co-operative society" as a possible club structure). In Germany, besides companies (Aktiengesellshaft - AG, Gesellschaft mit beschränkter Haftung - GmbH, and $G m b H \& C o . K G$ auf Aktien), the eigetragene Genossenshaft - eG (i.e., the cooperative) is appointed as a possible legal form for sports clubs. Cf. the analysis of JOHANNES ERNING, Professioneller Fußball in Deutschland. Eine wettbewerbspolitische und unternehmensstrategische Analyse, Verlag für Wirtschaftskommunikation, Berlin, 2000, pp. 208 ff., specially 215 ff. JOHANNES ERNING, op. cit., p. 216, considers that the operation by which a club would leave the non-profit association to become a cooperative would not raise significant problems; on the contrary, it would present several advantages, making it a better alternative than creating a sports company (because of the constraints of a necessary profit-making objective in order to attract external investment, leading to the existence of "principal-agent" conflicts).

${ }^{15}$ Cf. Armin Wiedenegger/Alexander Kern/Maria Rupprechter, "The Choice of Legal Form and its Effects on Good Governance: A Case Study of an Austrian Professional Soccer Club", cit., pp. $23 \mathrm{ff}$.

${ }^{16}$ Based on both the existing cooperative law in Europe and the EU regulation on the societas cooperativa europaea, the PECOL were drafted by a team of legal scholars, aiming to describe the common core of European cooperative law.

${ }^{17}$ Cf. Section 3.5 (1) of the PECOL principles: "Cooperatives have legal personality and enjoy patrimonial autonomy".

${ }^{18}$ As stated by Section 3.5 (2) of the PECOL principles, "[n]o member shall be liable for the debts of the cooperative for more than the amount they have subscribed, unless cooperative statutes provide for the liability of the member by guarantee subject to a cap". Despite the possibility of statutory exclu- 
economic activity without having profit as its ultimate purpose (in the sense of being willing to make profits mainly for the payment of interests, dividends or bonuses on money invested or deposited in, or lent to, the cooperative; however, there is no imposition on non-profit making - cooperatives can even distribute eventual profits among members, but face constraints when that distribution aims at remunerating capital). Although a cooperative may be established to carry out an activity in the general interest of the community (in the special case of a general interest cooperative), its activity is regularly carried mainly in the interest of its members (as consumers, providers or workers of the cooperative enterprise). This definition arises from the first provision of the PECOL ${ }^{19}$, and highlights the basic difference between cooperatives and (for-profit) companies ${ }^{20}$. But, as cooperatives carry out an economic activity in a corporate form and it is possible for them to distribute the economic results of their business to its members (essentially as cooperative refunds), they are also to be distinguished from non-profit associations strictu-sensu ${ }^{21}$.

Under Portuguese legislation, cooperative economic activity must be carried out in one or several of the following areas: consumption, trade, agriculture,

sion of limited liability, in the words of Gemma Fajardo/Deolinda Meira, "Cooperative financial structure", in VVAA, Principles of European Cooperative Law. Principles, Commentaries and National Reports, Intersentia, Cambridge/Antwerp/Portland, 2017, 73-95, p. 88, the trend is, nowadays, to exclude members' liability for the cooperative's debts.

${ }^{19}$ Art. 2 of the Portuguese Cooperative Code (PCC) defines cooperative as an autonomous association of persons, united voluntarily, of variable composition and capital, which, through cooperation and mutual assistance on the part of its members and in accordance with cooperative principles, aims not at profit but at satisfying the economic, social, or cultural needs and aspirations of said members. As is stated in Art. 17 PCC, a cooperative acquires legal personality when its incorporation is registered - and then, because the cooperative becomes a legal person, its assets are autonomous from its members' assets (which was not the case before: cf. Maria de Fátima RibeIro, "Artigo $18^{\circ}$ - Responsabilidade antes do registo", in Código Cooperativo Anotado (coord. Deolinda Meira e Maria Elisabete Ramos), Almedina, Coimbra, 2018, 109-115, pp. 109 ff.), and therefore the members are not liable for the cooperative's debts (cf. Deolinda Meira/Maria de Fátima Ribeiro, "Artigo 80 - Regime económico", in Código Cooperativo Anotado (coord. Deolinda Meira e Maria Elisabete Ramos), Almedina, Coimbra, 2018, 443-450, pp. 443 ff.). Under Portuguese law, cooperative rules must respect cooperative principles, embodied in Art. 3 of the PCC: voluntary and open membership; democratic member control; members' economic participation; autonomy and independence; education, training, and information; cooperation among cooperatives; and concern for the community.

${ }^{20}$ Cf. the analysis of AnTonio Ficci, "Definition and objectives of cooperatives", in VVAA, Principles of European Cooperative Law. Principles, Commentaries and National Reports, Intersentia, Cambridge/Antwerp/Portland, 2017, 19-45, pp. $20 \mathrm{ff}$.

${ }^{21}$ Cf. Deolinda Meira, "Portugal", in VVAA, Principles of European Cooperative Law. Principles, Commentaries and National Reports, Intersentia, Cambridge/Antwerp/Portland, 2017, 409-516, p. 416. 
credit, housing and building industry, working, crafts, fishery, cultural, services, education, and social solidarity ${ }^{22}$.

The cooperative's objective consists of, firstly, developing an economic activity, "mainly through cooperative transactions with their cooperator members for the provision of goods, services or jobs". In that sense, the cooperative is an enterprise, and cooperatives may engage in non-member cooperative transactions - unless otherwise defined by their status - as long as that activity is not their main activity ${ }^{2324}$. And second, the cooperative must develop such activity in the interest of its members, i.e., to "the (direct) satisfaction of the members" needs" 25 .

This mutual purpose, though, does not preclude that cooperatives pursue additional (altruistic) objectives, serving a sort of parallel social function. In fact, there is a "social dimension" in the economic activity of cooperatives, whose purpose consists equally of attending to the interests of the community within which the cooperative explores its business ${ }^{26}$. The principles of education, training and information illustrate this very dimension. Under Sections 2.3(4)(a) and 2.3(1)(d) of the PECOL principles, members have the right and the obligation to participate in education and training provided by the cooperative, "appropriate to their role in the cooperative"; and Section 2.6(3) states the importance of education on members' rights. Art. 3 of the PCC also illustrates this dimension, as it "emphasises the obligation of cooperatives to guarantee the education and training of their members, representatives of their elected bodies, directors, and employees in cooperative related beliefs and actions" 27 , which is also "vital for the functioning and governance of cooperatives" 28 .

Therefore, sports cooperatives could be created to explore the economic activities related to, e.g., amateur and professional football, providing their members with access to sports education, community sporting events, lower ticket prices and organised transport to games, equipment, merchandising. In such case,

${ }^{22}$ Cf. art. 4 of the PCC.

${ }^{23}$ Cf. Section 1.5 of the PECOL. Of course, this Section's rules only apply to transactions for the provision of goods, services or jobs of the same kind as those provided to cooperator members - all other transactions, instrumental to the main activity of the cooperative enterprise, are not limited by law. In this same sense, cf. Art. 2.2 of the PCC.

${ }^{24}$ Cf. Section 1.4 (1) of the PECOL.

${ }^{25}$ Cf. Antonio Ficci, "Definition and objectives of cooperatives", cit., p. 24; Gert van DiJK / Panagiota Sergaki / George Baourakis, The Cooperative Enterprise. Practical Evidence for a Theory of Cooperative Entrepreneurship, Springer International Publishing, Berlin, 2019, pp. $48 \mathrm{ff}$.

${ }^{26}$ Cf. Deolinda Meira, "Portugal", cit., pp. $421 \mathrm{ff}$.

${ }^{27}$ Cf. Deolinda Meira, "Portugal", cit., p. 422.

${ }^{28}$ Cf. Inn SNaith, "Cooperative Governance", in VVAA, Principles of European Cooperative Law. Principles, Commentaries and National Reports, Intersentia, Cambridge/Antwerp/Portland, 2017, 47-71, p. 72. 
a sports cooperative would pursue cooperative economic activities in more than one of the allowed areas, namely in consumption, culture, services and education. The sports cooperative would exist to serve its members (although it would be free to conduct business with non-members, as long as it predominantly traded with members - such as participants, fans, or investors). All embers would be given the opportunity to benefit from the economic activity of the cooperative and to participate in its governance, whilst being granted limited liability.

The social dimension of cooperatives is also relevant to football clubs. Under Portuguese law, the State counts on private entities to collaborate in the pursuit of some collective rights - namely by promoting access to physical activity and sports (and these are constitutional rights $\left.{ }^{29}\right)^{30}$. Therefore, establishing the club as a standalone company is not an adequate solution for its legal form. The company will necessarily have a profit-making objective, so any activity that is not aimed at generating profit infringes its objective, which is a source of severe problems ${ }^{31}$.

But there is more: any resources allocated to these private entities dedicated to serving some kind of public interest ${ }^{32}$ would be difficult to integrate in the scope of a profit-making company. Since, again, companies are not created to serve public interests, and those resources could end up in the hands of the shareholders, who are interested in profit-making. Sports companies should direct these resources to their funding clubs, but there are some limitations to this solution: the company could have been created without the existence of a funding club (which is possible under Portuguese legislation); and the relationship between a professional football company and its funding club is not always the best (so this can be - and sometimes is - wrongfully used in a context of conflict, aggravating it).

\section{MEMBERSHIP IN COOPERATIVES AND PROFESSIONAL FOOTBALL}

Section 2.2 establishes the open membership principle: "membership of a cooperative must be open to any person able and willing to accept the responsibilities of membership"; any limitation to this principle must be based on the ability to use the cooperative's services ${ }^{33}$. But the "open door principle" does not give

\footnotetext{
${ }^{29}$ Cf. Art. 79 of Constituição da República Portuguesa.

${ }^{30}$ Cf. Art. 5.3 of Lei $n^{\circ}$ 5/2007, de 16 de Janeiro.

${ }^{31}$ Cf. Maria de Fátima Ribeiro, Sociedades Desportivas, cit., pp. 35 ff.

32 V.g., the UEFA club competition solidarity payments for youth development in UEFA member association top-division clubs - the amount is to be distributed to national associations and/or leagues for their clubs and, as seen before, only sports companies are allowed to participate in professional football competitions, so only sports companies are members of the Portuguese football league and will receive a share of this payment.

33 "Cooperatives are voluntary organisations, open to all persons able to use their services and willing to accept the responsibilities of membership, without gender, social, racial, political or religious
} 
one the legally enforceable right to become a member - membership applications must be dealt with by a designated organ.

Members have obligations and rights. Concerning obligations, it is worth emphasising the duty to participate in cooperative transactions to a minimum extent $^{34}$, to make the applicable capital contributions, and to participate in the cooperative's governance (except for the case of investor members, who are neither obliged to participate in cooperative transactions, nor in the governance of the cooperative) $)^{35}$.

Members have individual and collective rights. Individual rights are, e.g., the right to participate in the cooperative's governance (attending meetings, voting, standing for election, requesting and receiving information), to receive dividends (only when decided under cooperative statutes), and to engage in cooperative transactions, receiving any cooperative refund (when determined by the competent organ). Collective rights also include the right to participate in the cooperative's governance (the right to request and receive any information, to propose candidates for election, to require a members' meeting to be called, to propose resolutions, to demand an audit of the cooperative by specially qualified and independent auditors), and to amend the cooperative's statutes or to restructure or dissolve the cooperative. Information is granted both as a collective and as an individual right, due to the value of transparency for member control of the cooperative $^{36}$.

A cooperative must have cooperator members (those members - natural or legal persons - who engage in cooperative transactions as consumers, providers or workers of the cooperative enterprise), and may have non-cooperator members (those members - natural or legal persons - who do not engage in cooperative transactions). Investors may be non-cooperator members, interested in the pursuit of the cooperative objective. Non-cooperative members can eventually be admitted to membership, if the cooperative's statutes provide accordingly. Cooperator members are contributors to the cooperative's capital as well. However, this participation is of a personal, non-capitalistic nature: rights and obligations have no link to the capital invested or the contribution made, but only to the member (and that is why shares in cooperatives, unlike shares in joint stock companies, cannot be traded on the securities market).

discrimination" is Principle 1, Voluntary and Open Membership, of the International Co-operative Alliance Principles, in https://www.ica.coop/en/cooperatives/cooperative-identity\#voluntary-andopen-membership.

${ }^{34}$ Cf. Art. 22.2.c) of the PCC.

${ }^{35}$ Cf. Section 2.3 (1) of the PECOL principles.

${ }^{36}$ Cf. Section 2.6 of the PECOL principles, and its analysis by IAN SNAITH, "Cooperative Governance", cit., p. 72. 
Consequently, member shares may not be freely transferred: only among members or candidates for membership. And even in that case, the transfer is always subject to approval by the designated organ (and to any other conditions established in the statutes). In addition, personal creditors of the members cannot request the attachment of the member shares. The shares subscribed by investor members are not freely transferrable, as the transfer will need to have the permission from a designated organ as well ${ }^{37}$.

In football-related economic activities, cooperatives may adequately pursue the interests of supporters (that can be cooperator members, which does not exclude the possibility of them investing in the cooperative), as well as the interests of mere investors (that can be non-cooperator members, not engaged in cooperative transactions, but eventually taking part in the decision-making process and having access to all relevant information).

\section{GOVERNANCE IN COOPERATIVES AND PROFESSIONAL FOOTBALL}

The cooperative governance structure is ruled under Sections 2.4 and 2.5 of the PECOL principles, which attribute a very significant role to cooperative members.

Members participate in policy-making and major decisions in the cooperative, respecting the democratic principle "one member one vote" (regardless of the amount of capital held). In small cooperatives, members participate in decisionmaking directly; in other cases, cooperatives have a structure that allows members to ultimately control the organisation through the members meeting (or a series of meetings, split by sectors, in cooperatives with a large or widely dispersed membership). These meetings are complemented by one or more boards of committees, responsible for day-to-day management and accountable to the members.

In a "one tier system", the administrative board has the powers of executive management and representation, and is supervised and monitored by the members' meeting (or by a smaller elected body, in cooperatives with a large or widely dispersed membership) and/or by subcommittees of the administrative board. In a "two tier system", the management board has the powers of executive management and representation, and is supervised and monitored by a supervisory board. The members of those organs must be elected and removed by the cooperative's members - and the majority of members of both the administrative and supervisory boards have to be cooperative members themselves.

The duties of cooperative board members and managers include, as stated in Section 2.5 (8), an obligation to adhere to the cooperative's defining values, prin-

${ }^{37}$ Cf. Section 3.3 (6) of the PECOL principles. 
ciples and practices, as well as the obligation to comply with the law and the cooperative statutes, and their "duties of honesty, loyalty, good faith, care and skill" 38 .

Section 2 of the PECOL principles rules cooperative governance. The fundamental general principle is, as stated in Section 2.1 (1), that cooperatives "are directed and controlled by or on behalf of their members, who have ultimate and democratic control through their governance system" 39 . Whichever governance structure is adopted for a cooperative's governance, the ultimate and imperative goal is to ensure cooperative autonomy and member control; and to pursue the specific economic activity mainly in the interest of the cooperative members ${ }^{40}$.

When it comes to professional football, supporters' participation is a fundamental tool for entrepreneurial success ${ }^{41}$. If supporters believe they have access to all relevant information, and can be a part of the decision-making process, they will invest in the club enterprise, either by acquiring goods and services, or by investing their capital. The cooperative governance structure promotes this necessary sense of trust, while still ensuring adequate levels of professionalism and control of management activity - which can equally reassure external investors.

\section{FinANCIAL STRUCTURE OF COOPERATIVES AND PROFESSIONAL FOOTBALL}

Cooperatives carry out an economic activity without having profitability as their ultimate purpose. Nevertheless, they are business organisations - and, for that reason, they can (and may need to) resort to various sources of capital, as long as these are compatible with their cooperative nature.

The economic resources of a starting cooperative are obtained through the contributions of cooperator members (which do not, as seen above, determine the rights of the members; what determines them are the mutual transactions between each member and the cooperative, because cooperatives need cooperative transactions with their members to conduct their economic activity ${ }^{42}$ ). Yet, making a

${ }^{38}$ Cf. Maria de FÁtima Ribeiro, "Anotação ao acórdão do Tribunal da Relação de Lisboa, de 19 de Abril de 2016 - A proibição de negociar com a cooperativa que impende sobre os membros dos seus órgãos de gestão e fiscalização", in Cooperativismo e Economia Social, ano 2016-2017, n. . 39, 315-325, pp. $315 \mathrm{ff}$.

${ }^{39}$ The member control principle also applies to general interest cooperatives. Cf. IAN SNAITH, "Cooperative Governance", cit., p. 48.

${ }^{40} \mathrm{Cf}$. Section 2.1 (3) and (5) of the PECOL principles.

${ }^{41}$ Even though there are limits and special rules related to the participation in sports companies, in order to avoid the manipulation of sportive results. Cf. MARIA DE FÁtIMA RIBEIRO, "A participação em sociedades desportivas", in V Congresso Direito das Sociedades em Revista, Almedina, Coimbra, 2018, 311-342, passim.

${ }^{42}$ Cf. Gemma Fajardo/Deolinda Meira, “Cooperative financial structure”, cit., p. 74. 
capital contribution cannot be seen as a necessary condition for acquiring membership, although legal rules or statutory provisions frequently establish that duty.

Remuneration of invested capital is not an absolute right of the members; however, if financial results are positive, the members' meeting may decide to pay interest (which is decided in the members' meeting) when the cooperative statutes so provide, ${ }^{43}$. In that case, the interest rate cannot be higher than a reasonable rate (just the "necessary to obtain and retain enough capital to run the business") 44 , but may vary according to the nature of the contribution (mandatory or optional) and the category of the members (v.g., cooperator or non-cooperator members $)^{45}$.

Unless stated in a legal or statutory provision, there is no legally required minimum capital ${ }^{46}$; and, in any case, the share capital is variable, in order to facilitate the free entry and exit of members (although the same can be achieved through the transfer of share capital participations). The stability of the cooperative's financial situation is still protected: if a member leaves the cooperative, they may not be reimbursed for the nominal value of their shares and their portion of divisible reserves ${ }^{47} /{ }^{48}$. In cooperatives there are mandatory (legal or statutory) reserves (which can only be used to cover a balance sheet loss) and voluntary reserves (as determined by the members' meeting $)^{49}$.

The economic results of a cooperative's transactions with members may result in either cooperative "surpluses" or cooperative losses. The allocation of an eventual "surplus" is decided by members' meeting: it can either be distributed to the cooperator members as cooperative refunds, or allocated to divisible and indivisible reserves.

In the first case, the use of the word "refund" expresses the very nature of the "surplus". Cooperatives do not have a profit-making purpose. If there is a "surplus", it must be the result of an excessive payment requested by the cooperative

\footnotetext{
${ }^{43}$ That is the rule stated under Article 88 of the PCC: a portion not exceeding $30 \%$ of the annual net results can be allocated to compensate for shares, based on the capital underwritten by members. Cf. Deolinda Meira, "Portugal”, cit., pp. 468 ff.; idem, "Artigo 88 - Remuneração dos títulos de capital", in Código Cooperativo Anotado (coord. Deolinda Meira e Maria Elisabete Ramos), Almedina, Coimbra, 2018, 484-487, pp. 485 ff.

${ }^{44}$ That is, "this rate may never be speculative, since the principle of member economic participation limits compensation": cf. Deolinda MeIRA, "Portugal", cit., p. 468.

${ }^{45}$ Cf. Section 3.3 of the PECOL principles.

${ }^{46}$ In some legal systems, in fact, a minimum share capital is imposed to cooperatives.

${ }^{47}$ Cf. Section 3.3 (7) of the PECOL principles.

${ }^{48}$ Cf. Maria de FÁtima Ribeiro, "Os interesses do cooperador demissionário e a tutela do património e dos credores da cooperativa", in Jurisprudência Cooperativa Comentada. Obra Coletiva de Comentários a Acórdãos da Jurisprudência Portuguesa, Brasileira e Espanhola (coord. Deolinda Aparício Meira), Imprensa Nacional-Casa da Moeda, Lisboa, 2012, 375-386, pp. 375 ff.

${ }^{49} \mathrm{Cf}$. Section 3.4 of the PECOL principles.
} 
to the members, or of a lower price than necessary paid by the cooperative to its members in cooperative transactions. And if the members did pay more, or receive less, than due, they will be refunded. This explains why the members will receive the refunds in accordance with the quantity or quality of their participation in cooperative transactions.

According to the law of several European countries, cooperative surpluses can only be distributed if they are not needed to cover existing losses, and to that extent $^{50}$. This rule aims to preserve the cooperative's solvency ${ }^{51}$.

If the results of the cooperative transactions are losses, they may be covered either by using the reserves or by cooperator members' contributions. Both would have to be stipulated by the members' meeting. The participation of the cooperator members in covering losses has a limit: although it is also determined in accordance to the quantity or quality of their participation in cooperative transactions (the same rule that applies to refunds), it can never surpass the value of the goods and services received by each member.

Despite the non-profit nature of cooperatives, a cooperative may have real profits, i.e., results that do not derive from the transactions between the cooperative and its members (v.g., results from non-member cooperative transactions, or from the ownership of company shares or other assets). These results cannot be distributed - their only possible use is to be allocated to indivisible reserves. In the case of losses caused by non-member cooperative transactions and other sources, the limited liability of cooperative members will come into effect: they will not have to cover those losses, which can only be covered by the cooperative's reserves ${ }^{52}$.

A cooperative may have access to other sources of funding besides shares, mutualistic capital, or an admission fee. The Portuguese legal system provides cooperatives with the very interesting possibility of issuing investment securities (inspired by the participating shares of companies) or bonds (in accordance to the standards established for companies by Portuguese company law, and as long as this does not harm the cooperative principles or the rules of the $\mathrm{PCC}^{53}$ ), if the general meeting decides so $^{54}$. Those instruments can, of course, be subscribed by

\footnotetext{
${ }^{50}$ That's the case of the Portuguese Cooperative Code (art. 100.2).

${ }^{51}$ Cf. Gemma Fajardo/Deolinda Meira, "Cooperative financial structure”, cit., p. 91.

${ }^{52} \mathrm{Cf}$. Section 3.7 of the PECOL principles.

${ }^{53}$ Cf. Article 95 of the PCC and Margarida Azevedo Almeida, "Artigo 95 - Obrigações", in Código Cooperativo Anotado (coord. Deolinda Meira e Maria Elisabete Ramos), Almedina, Coimbra, 2018, 516-519, pp. $516 \mathrm{ff}$.

${ }^{54}$ Cf. Article 90.3 of the PCC.
} 
non-members, but cooperators have pre-emptive subscription rights for convertible investment securities ${ }^{55}$.

When issuing investment securities, it is the general meeting that determines the interest rate. It may also determine that underwriters have the right to participate in general meetings, when they are not already cooperator or investment members (always without voting rights) ${ }^{56}$. It may also give underwriters the right to elect a representative who is entitled to attend the meetings of the supervisory board and to access all the information provided to its members ${ }^{57}$ - which makes those instruments very reliable for all interested investors.

Therefore, investment securities can be a rather relevant source of funding for a cooperative, attracting even non-members' investment, without putting its political autonomy at stake ${ }^{58}$. There are, however, limits on their issuance: they must not exceed the amount of the existing paid-up capital, in accordance to the most recent approved financial statements, plus any amount of increased capital paid after their closing date ${ }^{59}$.

Nowadays, financial performance is a very relevant topic in professional football: clubs lack financial investment, and several clubs are even living in a state of financial distress, leading to insolvency. It is important to attract investment, and to have rules that protect all investment made in a club, without disregarding investors' expectations. So, cooperative members benefit from cooperative transactions; and investor members benefit from the remuneration of the capital they invested. In parallel, investors can be reassured by their "control" over the cooperative's management, because they have some important participation rights in the cooperative's organisation - such as voting, electing members of the boards, and having access to relevant information. Furthermore, under some national cooperative legal systems (as the appointed PCC), cooperatives may issue investment securities and bonds, allowing and facilitating access to the investment of non-members.

Consequently, cooperatives' financial rules can provide adequate security and remuneration for all invested capital, and ensure essential creditor protection, without putting the fundamental principles that characterise their nature at stake.

${ }^{55} \mathrm{Cf}$. Article 91.4 of the PCC. The rule does not exist for bonds, because convertible bonds are not allowed on cooperatives: cf. Article 95.2 PCC.

${ }^{56} \mathrm{Cf}$. Articles 92.1 and 92.3 of the PCC.

${ }^{57}$ Cf. Article 94 of the PCC.

58 Cf. Margarida Azevedo Almeida, “Artigo 91º - Títulos de investimento", in Código Cooperativo Anotado (coord. Deolinda Meira e Maria Elisabete Ramos), Almedina, Coimbra, 2018, 500-505, p. 502.

${ }^{59}$ Cf. Article 92.4 of the PCC. 


\section{COOPERATIVES' FINANCIAL AND MANAGEMENT AUDIT AND PROFESSIONAL FOOTBALL}

The general principle of cooperative audit supports the role of the cooperative's financial structure as described above. As stated in Section 4.1 of the PECOL principles, and developed in Sections 4.2, 4.3 and 4.4, cooperatives are subject to being audited as a form of external control ${ }^{60}$ to ensure both their autonomy and their financial control (in order to protect their members, creditors and other stakeholders, as well as their ability to pursue their objectives).

Cooperative financial audits focus, much like company financial audits, on assessing "operational efficiency and economic results, including performance of the management (prudence and care) and compliance with the law". But cooperative audits are expected to go further than company audits, as they also assess "member-oriented effectiveness", by means of a management audit (including the respect of all rules that define member promotion, mutual aim, and structural democracy $)^{61}$.

Despite the differences in the ways in which external control is regulated in EU member states ${ }^{62}$, financial control is strictly regulated - and the trend is towards harmonisation of the management audit. Therefore, it can be concluded that audits in cooperatives are undoubtedly far more efficient than in unincorporated associations or even in companies limited by guarantee; and can be far more efficient than in some types of companies, especially in private limited liability companies, where audit rules are, under certain countries' legislations, very poor ${ }^{63}$.

The rules of cooperative audit can be very reassuring in addressing the issues currently faced by professional football. The legal rules concerning external au-

${ }^{60}$ That supplements internal audit and member control. Cf. HANs-H. MüNKNER, "Cooperative audit", in VVAA, Principles of European Cooperative Law. Principles, Commentaries and National Reports, Intersentia, Cambridge/Antwerp/Portland, 2017, 97-118, p. 97.

${ }^{61}$ Cf. Hans-H. MünKner, "Cooperative audit", cit., pp. 97 ff.

${ }^{62}$ The German Cooperative Societies Act of 2006 is an example of careful regulation on internal and external control of cooperatives. Cf. Hans-H. Münkner, "Germany", in VVAA, Principles of European Cooperative Law. Principles, Commentaries and National Reports, Intersentia, Cambridge/Antwerp/ Portland, 2017, 253-345, pp. $281 \mathrm{ff}$. and $319 \mathrm{ff}$. For the analysis of the Portuguese cooperative rules on the demanding internal and external control, cf. Deolinda Meira, "Portugal", cit., pp. $487 \mathrm{ff}$.

${ }^{63}$ In Portugal, the regulation of the sociedade por quotas does not impose the existence of neither an internal organic audit, nor an external audit. If the volume of certain business indicators consistently surpasses certain limits, the company will be obliged to have an accountability audit organ - but, precisely, its attributions are restricted to the audit of the accountability. The company will only be subjected to any kind of management audit if it wishes to do so. Cf. Maria de Fátima Ribeiro, "O regime das sociedades desportivas", in Direito do Desporto (coord. José Manuel Meirim), Universidade Católica Editora, Lisboa, 2017, 35-46, pp. $40 \mathrm{ff}$. Therefore, we can say that cooperative audit is far stricter than the audit of this type of company - and, under Portuguese law, the sociedade por quotas is legally admitted in the participation of professional football competitions. 
dits of cooperatives are similar to those of company law; and there is a growing internal demand for professionalism of audit functions. As seen above, this is a fundamental issue for a professional football club organisation.

But this trend could, per se, increase the distance between members and the cooperative - that is the reason why it is important to maintain all traditional principles of cooperative management audit, while preserving the members' fundamental role in the governance of cooperatives. This means that cooperatives can, simultaneously, provide all the means for an efficient accountability and management audit (which is important to attract and keep external investment) and the true participation of all the cooperative and investor members. That can reassure both supporters and external investors, for both need to feel they cannot lose control of the club's governance. The cooperative audit model can be used to keep the difficult balance between the conflicting interests of these two types of fundamental stakeholders.

\section{THE POSSIBLE ADVANTAGES OF COOPERATIVES AS THE LEGAL STRUCTURE OF CLUBS IN PROFESSIONAL AND AMATEUR FOOTBALL}

Non-profit associations are non-profit legal persons but do not have the purpose of carrying out an economic activity, which cooperatives do. Cooperatives are real enterprises "dedicated to the production of goods and services with a rationale that entails the maximisation of results and the containment of costs [...]. We are, therefore, in the presence of a business organisation with stated economic aims that are pursued in an economical manner: that is, one designed to achieve, for the benefit of members, a cost of goods lower than could be obtained by other means [...]. It is, however, a business entity with the specific aim of pursuing a mutualist purpose, which means that a cooperative' $s$ corporate activities are necessarily directed towards its members, who are the main beneficiaries of the economic and social activities that it carries out" ${ }^{\prime 64}$.

This makes cooperatives a more efficient legal organisational form for football clubs than associations. And, unlike cooperatives, associations do not assure member participation in business activities (as it is "merely circumstantial") ${ }^{65}$. Non-profit associations could be an adequate legal structure for amateur football, but clearly do not meet all the challenges the professional football business raises: governance and investment problems need to be solved within a much different organisational model.

\footnotetext{
${ }^{64}$ Cf. Deolinda Meira, "Portugal", cit., p. 418.

${ }^{65}$ Cf. Deolinda Meira, "Portugal", cit., p. 416. 
Profit-making companies have also shown to be less efficient than expected in solving those same problems, and their proliferation has led to an additional issue: the frequently tense relation between clubs and the companies they funded. That tension does no more than mirror the obvious tense relation between supporters and external investors, as well as the uncertainty about the exact borders of the social and entrepreneurial functions that should be accomplished by the club association and by the sports company. This has been a grey zone, putting the public service dimension of this social phenomenon at stake. And "there is a fundamental difference in the relationship between a company and its shareholders. The relationship between them is purely an investment relationship. So, the shareholder only needs to monitor the profit the enterprise makes, or the return on the capital invested. (If the shareholder is not happy with it, he can always get out). However, the members of a cooperative not only have an investment relationship with their enterprise; they also have a transaction relationship, which forms the core" ${ }^{166}$. This makes cooperatives more suitable to answer the specific issues of conciliating the two apparently different roles of being a member of the organisation and a supporter of the professional football team.

Therefore, the cooperative form of organisation could provide an alternative to the present dual structure, thus supressing the agency and transaction costs it entails. Cooperatives are appealing to supporters, as they provide them with goods and services, while allowing them to participate in the sportive project as well as in the cooperative organisation itself. This leads to sportive and financial success - particularly because supporters can be financial investors, too. They are also able to attract external investors: their governance structure generates confidence, by giving investors the possibility to have a voice within the cooperative's organisation, as investor members (without being a threat to the power of the other corporate members), and by establishing financial and management audit rules.

Finally, public interest would also benefit from the fact that the same "person" is pursuing private and public interests (combining the functions of the non-profit association and the profit-making company), with all the reassuring transparency and control that cooperative legislation can provide.

Let us consider, on this matter, an important issue under Portuguese law. Article 27.2 of the Lei de Bases da Actividade Física e do Desporto ${ }^{67}$ states that the law that rules sports companies must necessarily preserve the destination of the company's real estate. The meaning of this rule is not clear, but at least it must be understood as a symptom of the social dimension of sports clubs. Additionally,

${ }^{66}$ Cf. Gert van Dijk / Panagiota Sergaki / George Baourakis, The Cooperative Enterprise. Practical Evidence for a Theory of Cooperative Entrepreneurship, cit., p. 48.

${ }^{67}$ Lei n. ${ }^{\circ}$ 5/2007, de 16 de Janeiro. 
Article 27 of the Lei das Sociedades Desportivas ${ }^{68}$ states that, when a sports company is wound up, the real estate that houses sports facilities must be allocated to the founding club (the founding sports association) and continue to serve the same sports activity, if not needed to pay the company's debts. This rule raises several problems: there may be no founding club; and, under general company law, the shareholders are entitled to the final profit (as well as to the annual profit). If the founding club has to pay the other shareholders their part of the final profit, in order to keep the property of that real estate, it could get into serious financial problems, because sports facilities are valuable. And if it were to be assumed that this special rule overrules the general rule, in order to deny shareholders of a sports company the right to receive that share of the final profit, this would certainly discourage the investment on sports companies' shares - which is not acceptable given the financial circumstances surrounding professional football ${ }^{69}$.

Cooperative principles effectively address this problem. According to Section 3.8 of the PECOL principles, in case of liquidation of a cooperative, once the cooperative debts are paid, members shall only be entitled to recover the nominal value of their shares and their portion of divisible reserves as provided in cooperative statutes. Any residual net assets shall be distributed in accordance with the principle of disinterested distribution, e.g., distributed to the community or other associated cooperatives ${ }^{70}$. Under Article 114 of the PCC, when a cooperative is wound up residual assets cannot be distributed to members - they may be transferred with the same purpose to a new cooperative entity to be formed following the merger or the spin off of the cooperative in liquidation. Or, when no new cooperative succeeds the wound up cooperative, they will be allocated to another cooperative, preferably from the same city, as determined by the federation or confederation that represents the cooperative's main activity. We can therefore conclude that where special and controversial rules have to be imposed on sports companies, which conflict with a company nature, the cooperative principle of disinterested distribution ${ }^{71}$ provides the adequate solution.

In summary, despite the obvious need for further developments on this matter, cooperatives may in fact be an adequate form of legal organisation for both amateur and professional football clubs.

\footnotetext{
${ }^{68}$ Decreto-Lei n. ${ }^{\circ}$ 10/2013, de 25 de janeiro.

${ }^{69}$ Cf. Maria de Fátima Ribeiro, Sociedades Desportivas, cit., pp. 37 ff.

${ }^{70}$ Cf. Gemma Fajardo/Deolinda Meira, "Cooperative financial structure", cit., pp. $93 \mathrm{ff}$.

${ }^{71}$ Cf. Deolinda Meira, "Artigo 114 - Destino do património em liquidação", in Código Cooperativo Anotado (coord. Deolinda Meira e Maria Elisabete Ramos), Almedina, Coimbra, 2018, 607-610, pp. $608 \mathrm{ff}$.
} 